\title{
Archaeological Test Excavation At Site 41MX23 Morris County, Texas
}

Joe T. Denton

Follow this and additional works at: https://scholarworks.sfasu.edu/ita

Part of the American Material Culture Commons, Archaeological Anthropology Commons, Environmental Studies Commons, Other American Studies Commons, Other Arts and Humanities Commons, Other History of Art, Architecture, and Archaeology Commons, and the United States History Commons

Tell us how this article helped you.

This Article is brought to you for free and open access by the Center for Regional Heritage Research at SFA ScholarWorks. It has been accepted for inclusion in Index of Texas Archaeology: Open Access Gray Literature from the Lone Star State by an authorized editor of SFA ScholarWorks. For more information, please contact cdsscholarworks@sfasu.edu. 


\section{Archaeological Test Excavation At Site 41MX23 Morris County, Texas}

\section{Licensing Statement}

This is a work produced for the Texas Department of Transportation (TxDOT) by the report producer. TxDOT and the report producer jointly own all rights, title, and interest in and to all intellectual property developed under TXDOT's contract with the report producer. The report may be cited and brief passages from this publication may be reproduced without permission provided that credit is given to both TxDOT and the report producer. Permission to reprint an entire chapter, section, figures or tables must be obtained in advance from either the Supervisor of the Archeological Studies Branch, Environmental Affairs Division, Texas Department of Transportation, 125 East 11th Street, Austin, Texas, 78701 or from the report producer. 
Archaeological Test Excavation

At Site $41 \mathrm{M} \times 23$

Morris County, Texas

By

Joe T. Denton

Texas

State Department of Highways and Public Transportation Highway Design Division

October 1985 
Testing to determine the significance as a State Archaeological Landmark and to determine eligibility to the National Register of Historic Places was undertaken in June 1984 of Site $41 \mathrm{MX} 23$, Morris County, Texas, on FM 3421. The test shows that portion of the site within the project's rightof-way to be sparse in cultural material. The deposits containing the material vary from very shallow to moderate in depth. Testing indicates that insufficient cultural materials exist within the area to be impacted to warrant further investigations. 


\section{INTRODUCTION}

Archaeological Site 41MX23 was reported in April 1982 by a member of the State Department of Highways and Public Transportation (SDHPT) A rchaeology Section and was recommended for testing. Testing was conducted by two members of the SDHPT Archaeology Section and by SDHPT personnel provided by the SDHPT Mt. Pleasant Residency and Daingerfield Maintenance Offices. Test excavations were conducted during the period of June 25 through June 28, 1984, under provisions of the Memorandum of Understanding between the SDHPT and the Texas Antiquities Committee. Approximately 120 manhours were expended conducting the test.

The site was tested in order to determine the nature and cultural context of the deposits, a determination necessary for recommendation of additional investigation. Specific objectives were to define the boundary of the site within the SDHPT right-of-way and the depth, condition, and cultural significance of the site. 


\section{PROJECT DESCRIPTION}

Impact to Site $41 \mathrm{M} \times 23$ Will be the direct result of the construction of FM 3421. The project consists of the realignment and widening of a present two-lane county road (Fig. 1). The existing road will be widened to provide for a two-lane roadway with $22 \mathrm{ft}$. surface and $6 \mathrm{ft}$. earth shoulders. The present alignment will be followed with new alignment to eliminate severe curves. Existing roadway width varies from 30 to $40 \mathrm{ft}$. and will be widened to $120 \mathrm{ft}$. Project funding will be with State funds.

The area is presently rural with industrial iron-ore open pit mining. Principal vegetation consists of interspersed pastures and woodlands. Pastures are generally native grasses with some improved grasses. Woodlands consist of mixed pine, oaks, elms, hickory, and gum. Some pastures, including the area of the site, have undergone severe alteration by terracing. 
This Page Redacted Per THC Policy 


\section{SITE DESCRIPTION}

Archaeological Site $41 \mathrm{MX} 23$ is located on the west side of South Union Creek, approximately $2500 \mathrm{ft}$. east of the intersection of the county road and US 259 (Fig. 2). The site is on the edge of a relatively flat hilltop overlooking the valley formed by South Union and Peacock Creeks. The site today is pasture with no standing timber to the south of the existing roadway. Mixed timber covers the hill north of the roadway where it has not been determined that the site exists. New right-of-way is limited principally to the south of the existing roadway at this location.

Soils consist of fine sands of varying depths over sandy clay. The sands vary from gray to light tan. In Test Units 2, 5, and 6, the sands were generally uniform with indistinct boundaries, grading from a gray into a light tan. In Test Units 1, 3, and 4, the sands were reddish tan and deposits were very thin, generally less than $10 \mathrm{~cm}$. The sand deposits overlay a red sandy clay which is exposed along the existing roadway and the western $1 \mathrm{imits}$ of the site. Clay is also exposed in some areas downslope and in the areas where terracing has mixed the soils.

Test Unit 5 provided the deepest test at the site. The soil in this unit (Fig. 3) consisted of a mixed zone of sand and clays approximately 5 to $20 \mathrm{~cm}$ in depth. This zone was recent and a result of the terracing on the site. This zone overlay a gray fine sand which contained most of the cultural materials. This zone was approximately $30 \mathrm{~cm}$ thick.

This zone graded into a light tan fine sand approximately $30 \mathrm{~cm}$ thick and without a distinct boundary. Both sand zones were often heavily disturbed by rodent burrows. The lower red sandy clay was mottled and contained hematite gravels. 


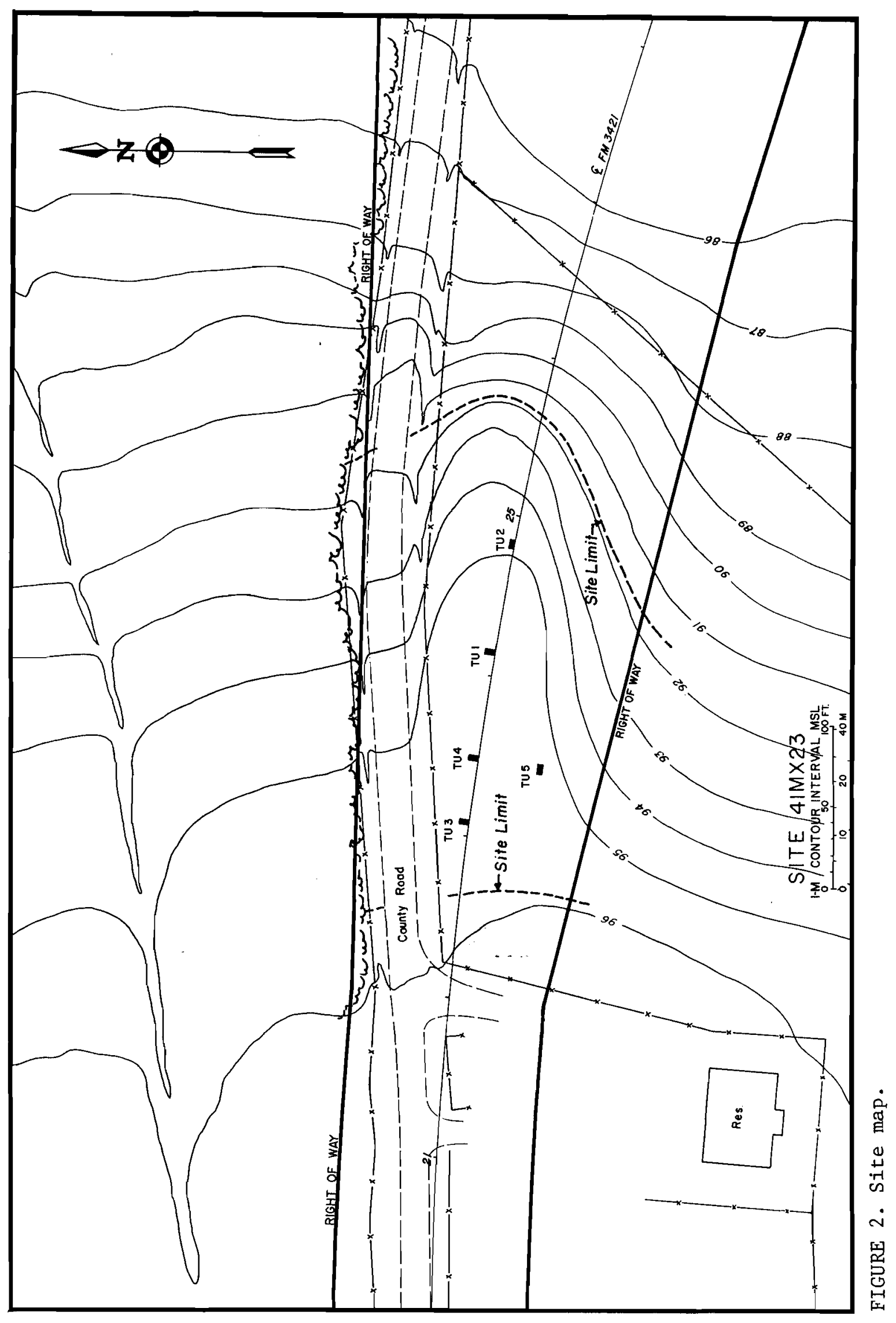




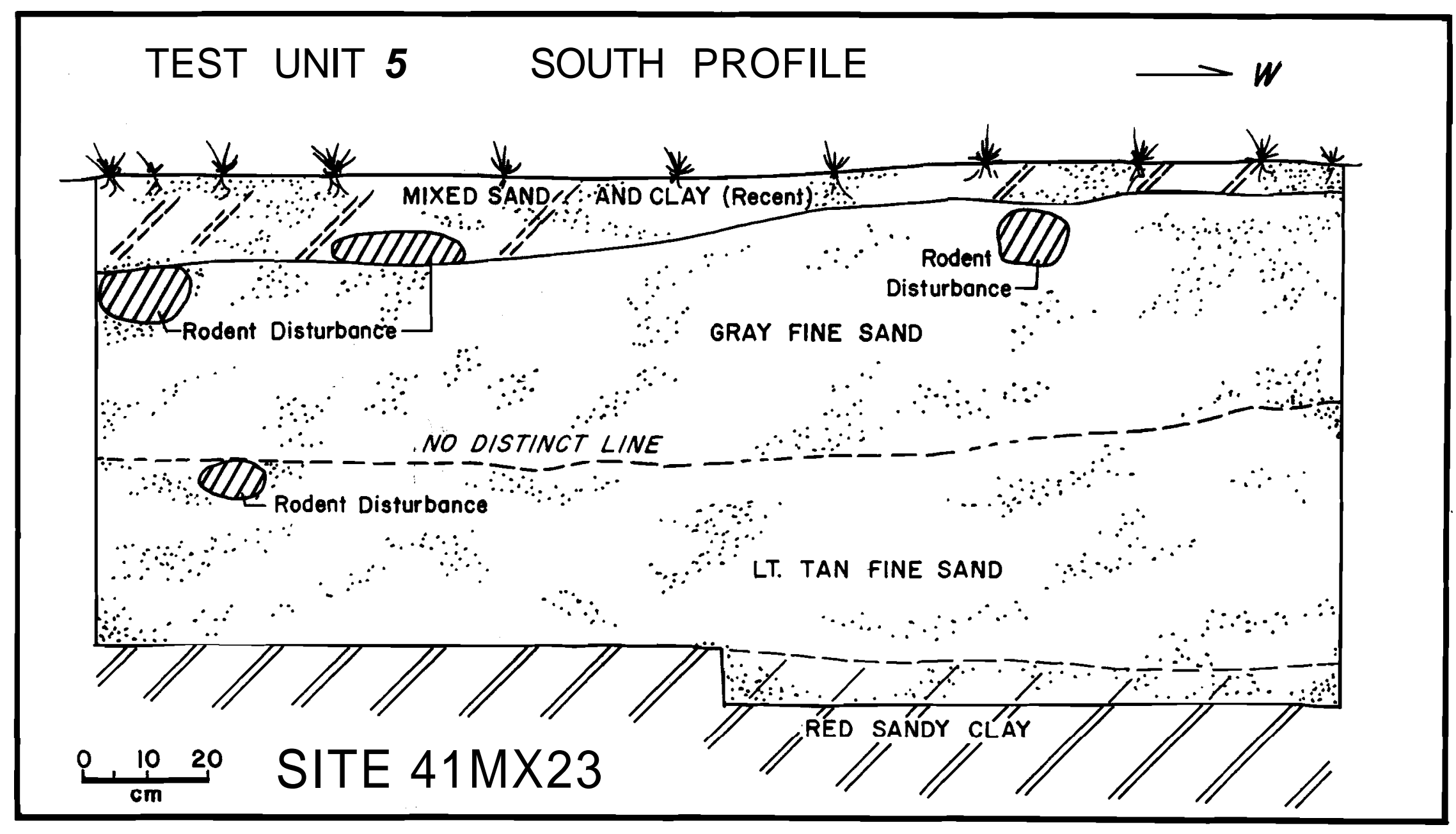

FIGURE 3. Profile of south wall of Test Unit 5. 


\section{EXCAVATION PROCEDURES}

The test excavations consisted of six $1 \times 2$ meter, hand-excavated units. These units were excavated to clay by shovel and trowel in $10 \mathrm{~cm}$ levels. The excavated soil was passed through .25 in. hardware cloth and all recovered cultural material was retained and bagged according to unit and level. The recovered material was removed from the site and taken to the SDHPT A rchaeology Laboratory for processing, analysis, and temporary storage. Field records consisted of daily notes, level reports, photographs, and project drawings.

Horizontal control was maintained by use of the project centerline, and vertical control of levels was measured from ground surface. Unit placement was along the centerline across the site, with one unit between the centerline and the south right-of-way line. The unit placement was anticipated to yield adequate information regarding the site limit and cultural deposits. 


\section{ARCHAEOLOGICAL BACKGROUND}

Most of the major sites in northeast Texas were excavated under operations of the Work Projects Administration (WPA). Numerous excavations have since been conducted but not to the extent of those of the WPA. Since the W PA, archaeological investigations have been conducted in the northeast portions of Texas principally in conjunction with reservoir projects. The purpose of this report is not to provide a detailed description of all the investigations but to provide a general overview of the prehistory of northeast Texas.

The Paleo-Indian Period is the earliest period recognized in northeast Texas as well as North America. This period is represented archaeologically by fluted and lanceolate projectile points, notably Clovis, Folsom, San Patrice, and Scottsbluff, as well as other diagnostic types. Isolated finds of Paleo-Indian projectile points are not a rarity in northeast Texas, but sites with numerous and extensive Paleo-Indian materials are not common.

The Paleo-Indian Period is followed by the Archaic Period which is distinguished by stemmed projectile points. The Archaic Period has been reported in the literature as the La Harpe Aspect (Johnson 1962). The La Harpe Aspect is represented in its early phase by Ellis and Yarbrough points, and in the middle and late phases by Gary points. The late phase is distinguished by the appearance of pottery.

Following the Archaic La Harpe Aspect is the Formative Period which has been divided into Pre-Caddoan and Caddoan phases. This Period is evidenced by the appearance of numerous pottery styles and by the introduction of arrowpoints in the Caddoan phase. The Caddoan phase began around A.D. 1000 and continued until historic contact. The Caddoan phase has been divided into five divisions (Davis 1970). 


\section{ARTIFACTS}

A total of 12 prehistoric artifacts (Fig. 4) and 67 flakes and chips was recovered during the test. The lithic artifacts consist of a single projectile point basal fragment (Fig. 4A), a lateral biface fragment (Fig. 4B), and a fragment of a polished hematite axe (Fig. 4C). Three cores (Fig. 4G-I) also were recovered. Nonlithic artifacts include 6 potsherds (Fig. 4D-F) and 2 cut nails.

The 6 sherds appear to represent fragments of $\mathbf{3}$ vessels. Three sherds are brushed and represent one vesel (Fig. 4D). One decorated rim sherd was recovered with what appears to be an incised subrectangular design below the lip of the sherd (Fig. 4E). The rim has a slight lip. The two remaining sherds form a portion of a $\mathrm{r}$ im from a smooth-sided bowl and exhibit no decoration (Fig. 4F).

A majority of the flakes and chips are less than $1 \mathrm{~cm}$ square in size and are of chert or petrified wood. 


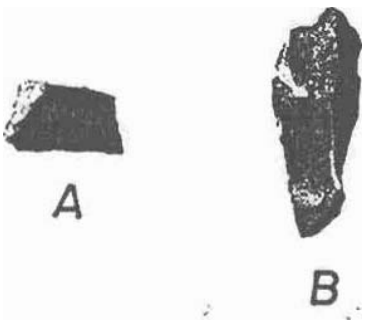

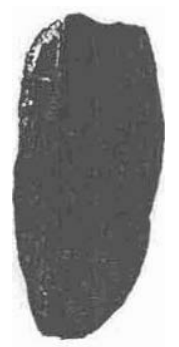

C

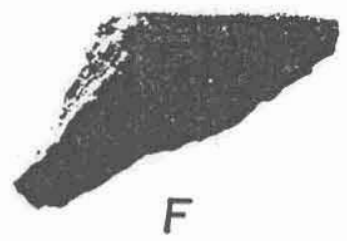

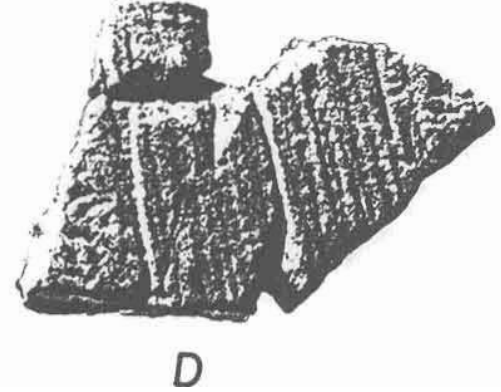

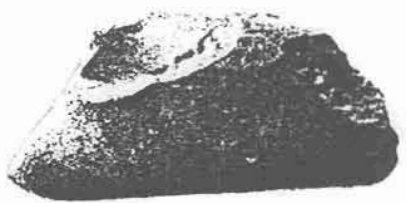

G
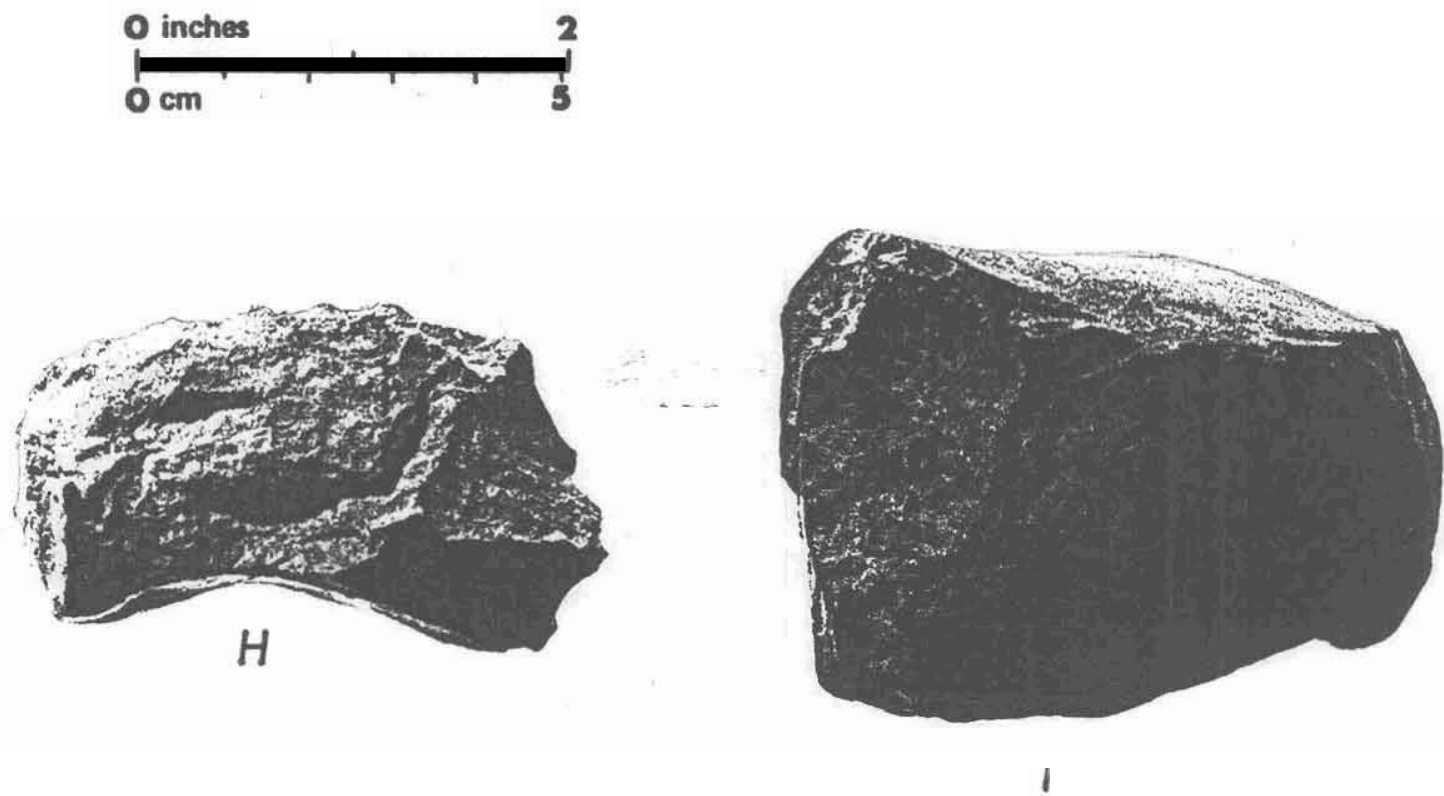

FIGURE 4. Artifacts. A, dart point basal fragment; B, biface fragment; C, hematite axe fragment; D-F, potsherds; $G-I$, cores. 


\section{OBSERVATIONS}

Almost a 11 material recovered was contained in the central portion of the test area. Test Unit 2 downslope produced flakes as did Test Units 3 and 4 on the level portion away from the break of the hill. While some lithic debris was present in all test units, only one unit (Test Unit 5) produced any pottery. This unit had the deepest deposit $(60 \mathrm{~cm})$ and was also the closest to the edge of the right-of-way. Although unconfirmed by testing, it is believed that the deep sand continued to the south of the testing area, outside of the SDHPT right-of-way.

Analysis of the lithic debitage indicates that the greatest concentration of cultural material was in the upper $30 \mathrm{~cm}$ of the deposit, with the greatest concentration in Level 1 and decreasing with depth. On the basis of the artifacts recovered, it may be speculated that the site, as tested, represents two brief occupations--the first during the Late Archaic La Harpe Aspect and the second during the Caddo IV Phase of the Late Prehistoric Period. 


\section{CONCLUSIONS AND RECOMMENDATIONS}

The site, Site 41MX23, appears to have limited value to studies in northeast Texas prehistory. The site, as tested, appears to have a sparse density of cultural debris which is further confused by a lack of stratigraphic context and by natural as well as man-made disruptions to the deposits.

It is believed that the portion of the site contained within the right-ofway does not meet the criteria for inclusion within the National Register of Historic Places and that the portions of the site within the right-of-way do not warrant further work. The portions of the site outside of the right-ofway are presently unaffected by any future projects. Less than $25 \%$ of the site, as tested, will remain within the SDHPT right-of-way, and therefore the site does not warrant Texas Archaeological Landmark status. 
Davis, E. Mott 1970

Archeological and Historical Assessment of the Red River Basin in Texas in Archeological and Historical Resources of the Red River Basin, edited by H. A. Davis, pp. 27-65. Arkansas Archeological Survey Research Series 1.

Johnson, LeRoy, Jr.

1962 The Yarbrough and Miller Sites of Northeastern Texas with a Preliminary Definition of the La Harpe Aspect. Bulletin of the Texas Archeological Society 32:141-248. 